Article

\title{
Laccase Immobilization by Chelated Metal Ion Coordination Chemistry
}

\section{Qingqing Wang, Jing Cui, Guohui Li, Jinning Zhang, Fenglin Huang and Qufu Wei *}

Key Laboratory of Eco-Textiles, Ministry of Education, Jiangnan University, Wuxi 214122, China; E-Mails:wqq888217@126.com (Q.W.); cuijing09@163.com (J.C.); leeanna101121@yeah.net (G.L.); 18762671766@163.com (J.Z.); windhuang325@163.com (F.H.)

* Author to whom correspondence should be addressed; E-Mail: qfwei@jiangnan.edu.cn; Tel.: +86-510-8591-3653; Fax: +86-510-8591-2009.

Received: 4 May 2014; in revised form: 28 July 2014 / Accepted: 26 August 2014 / Published: 15 September 2014

\begin{abstract}
In this work, amidoxime polyacrylonitrile (AOPAN) nanofibrous membrane was prepared by a reaction between PAN nanofibers and hydroxylamine hydrochloride. The AOPAN nanofibrous membranes were used for four metal ions $\left(\mathrm{Fe}^{3+}, \mathrm{Cu}^{2+}, \mathrm{Ni}^{2+}, \mathrm{Cd}^{2+}\right)$ chelation under different conditions. Further, the competition of different metal ions coordinating with AOPAN nanofibrous membrane was also studied. The AOPAN chelated with individual metal ion $\left(\mathrm{Fe}^{3+}, \mathrm{Cu}^{2+}, \mathrm{Ni}^{2+}, \mathrm{Cd}^{2+}\right)$ and also the four mixed metal ions were further used for laccase (Lac) immobilization. Compared with free laccase, the immobilized laccase showed better resistance to $\mathrm{pH}$ and temperature changes as well as improved storage stability. Among the four individual metal ion chelated membranes, the stability of the immobilized enzymes generally followed the order as Fe-AOPAN-Lac $>\mathrm{Cu}-\mathrm{AOPAN}-\mathrm{Lac}>$ Ni-AOPAN-Lac $>$ Cd-AOPAN-Lac. In addition, the immobilized enzyme on the carrier of AOPAN chelated with four mixed metal ions showed the best properties.
\end{abstract}

Keywords: amidoxime polyacrylonitrile; metal chelation; laccase; immobilization; nanofibers

\section{Introduction}

Laccase is a copper-containing enzyme that can catalyze the oxidation of a wide variety of substrates with the concomitant four electron reduction of oxygen to water [1,2]. Due to its high efficiency, low cost, and good availability, it has been widely used in various applications including 
paper manufacturing [3], wood processing [4], environmental bioremediation [5,6], the food industry [7], as well as textile engineering [8]. However, it has been realized that free enzymes have the weakness of non-recyclability, and reusability in industrial applications. These problems can be well solved by enzyme immobilization.

Various methods concerning laccase immobilization have been reported, including entrapment, encapsulation, adsorption, covalent binding, as well as self-immobilization [9]. Among all these methods, adsorption is relatively simple and less expensive, so it may have a higher commercial potential than the other methodologies. Some studies have demonstrated that adsorption is preferable to other techniques for the immobilization of some particular laccases [10]. Recently, metal-based supports have been receiving emerging attention for metal-chelated enzyme adsorption [9]. Enzyme immobilization on metal chelated support is based on multipoint interactions between chelated metal ions on the support and the imidazole group of histidine, the indole group of tryptophan and the thiol group of cysteine [11]. The transition metal ions are considered strong Lewis acids and interact with strong Lewis bases such as nitrogen and oxygen [12]. In addition, $\mathrm{Cu}-$, Ca-, Al-, Zr-based supports have been studied for the laccase immobilization [12-15]. A general improvement in laccase activity and stability was observed with all these metal-based supports.

Electrospun nanofibers have been recognized as excellent supports for enzyme immobilization since they have a large surface area, high recovery and reusability of the enzymes [16]. Polyacrylonitrile (PAN) nanofibers after surface modification have been studied and proved to be ideal support for laccase immobilization [17]. Amidoxime polyacrylonitrile (AOPAN) prepared by the chemical modification of the nitrile group was known as good adsorbent for metal ions [18]. Feng [19] has proved that after immobilized onto the surface of Fe(III) chelated AOPAN nanofibrous membrane, catalase showed better stabilities. However, as far as we are concerned, metal ion chelated AOPAN nanofibers have not been used for laccase immobilization yet.

In this work, AOPAN nanofibrous membranes were obtained by a facile electrospinning process and followed by treatment in the aqueous solution of hydroxylamine hydrochloride. Four different metal ions $\left(\mathrm{Fe}^{3+}, \mathrm{Cu}^{2+}, \mathrm{Ni}^{2+}, \mathrm{Cd}^{2+}\right)$ were then chelated by AOPAN nanofibrous membranes. In addition, the metal ion chelated AOPAN nanofibrous membranes were then used to immobilize laccase, the mechanism of which was shown in Figure 1. The properties of the immobilized enzyme including optimum $\mathrm{pH}$ and temperature, storage stability as well as operational stability were investigated. Moreover, the AOPAN nanofibrous membrane chelated with these four mixed metal ions mentioned above was also used as substrate to evaluate its ability in enzyme immobilization.

Figure 1. Schematic illustration of laccase immobilized by amidoxime polyacrylonitrile (AOPAN)-metal chelated nanofibrous membrane.

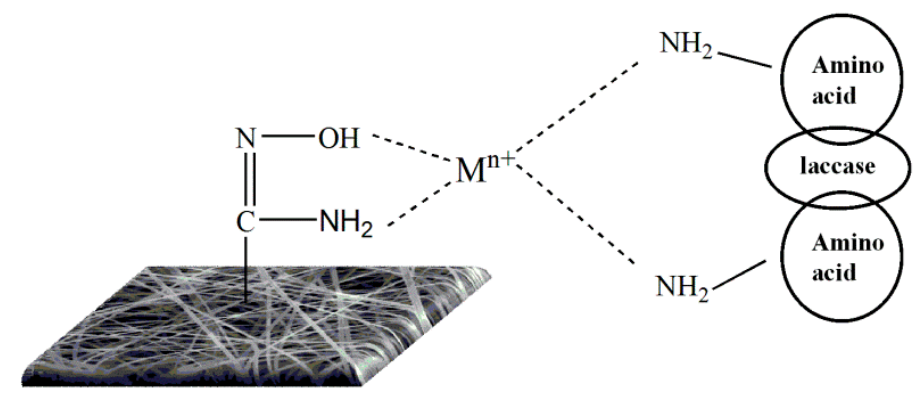




\section{Experimental Section}

\subsection{Materials}

The laccase produced by Ganoderma lucidum using submerged fermentation was donated by Ding, who has reported the process of the enzyme production and characterization in their work [20]. 2,2'-azino-bis-(3-ethylbenzothiazoline-6-sulfonic acid) (ABTS) was obtained from Richu Biosciences Co., Ltd. (Shanghai, China). PAN $\left(M_{\mathrm{w}}=50,000 \mathrm{~g} \cdot \mathrm{mol}^{-1}\right)$ was purchased from Shangyu Wu and Yue Economic and Trade Co. Ltd. (Zhejiang, China). All the other reagents used in this work were of analytical grade and were purchased from Sinopharm Chemical Reagent Co., Ltd. (Shanghai, China).

\subsection{Preparation of Metal Chelated Amidoxime PAN Nanofibrous Membranes}

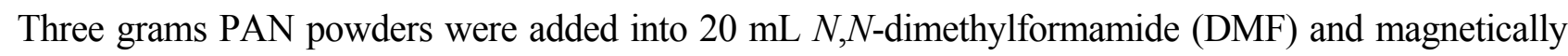
stirred for about $24 \mathrm{~h}$ until a homogeneous solution was obtained. Then the solutions were electrospun at a positive voltage of $15 \mathrm{kV}$ with a working distance of $15 \mathrm{~cm}$, and a flow rate of $0.5 \mathrm{~mL} \cdot \mathrm{h}^{-1}$.

The as-prepared electrospun nanofibers (about $0.2 \mathrm{~g}$ ) were then immersed in $50 \mathrm{~mL}$ of $20 \mathrm{~g} \cdot \mathrm{L}^{-1}$ hydroxylamine hydrochloride aqueous solution. The $\mathrm{pH}$ of the reaction solution was adjusted to 7 by adding sodium carbonate solution. The reaction was carried out at $50-60{ }^{\circ} \mathrm{C}$ for $2 \mathrm{~h}$. After being thoroughly washed, the AOPAN nanofibrous membranes were dried in vacuum oven at $50{ }^{\circ} \mathrm{C}$. The conversion of nitrile group in the PAN was calculated as follows [21]:

$$
C=\frac{\left(W_{1}-W_{0}\right) \times 53}{W_{0} \times 33} \times 100
$$

where $C(\%)$ is the conversion of the nitrile group into amidoxime group in the PAN, $W_{0}$ is the weight of the initial PAN nanofiber membranes, $W_{1}$ is the weight of the modified PAN nanofiber membranes, 53 and 33 are the molecular weights of acrylonitrile monomer and hydroxylamine, respectively. The conversion rate could be affected by temperature, reaction time and also the drying process, so it would be variable in different batches.

Certain amounts of ferric chloride, copper chloride dihydrate, nickel chloride, cadmium chloride were dissolved in deionized water with the final concentration of $1 \mathrm{~g} \cdot \mathrm{L}^{-1}$. The $\mathrm{pH}$ of the solution was adjusted to 4 by $\mathrm{HCl}(1 \mathrm{mM})$. Then the dried AOPAN nanofibrous membranes were separately put into a beaker with $50 \mathrm{~mL}$ metal salt solutions. After reaction for $72 \mathrm{~h}$ at $30{ }^{\circ} \mathrm{C}$, the membranes were taken out. After being thoroughly washed with deionized water, the membranes were dried in vacuum oven at $50{ }^{\circ} \mathrm{C}$.

\subsection{Immobilization of Laccase on Metal-Chelated AOPAN Nanofibrous Membranes}

The laccase was dissolved in acetic acid/sodium acetate buffer $(\mathrm{pH}=4.5)$ solution at the concentration of $3 \mathrm{~g} \cdot \mathrm{L}^{-1}$ by magnetic stirring for $20 \mathrm{~min}$ in ice bath. The supernatant was collected by centrifuging for $5 \mathrm{~min}$ and used for the following immobilization process.

The nanofibrous membrane (100 mg accurately weighed) was placed into the centrifuge tubes and then enzyme solution ( $8 \mathrm{~mL}$ per tube) was distributed into it. The immobilized laccase on AOPAN nanofibrous membrane before metal-chelation was described in our previous work [22]. 
The immobilization process was conducted in the refrigerator at $4{ }^{\circ} \mathrm{C}$ for $12 \mathrm{~h}$. After that, the membranes were taken out and washed thoroughly with buffer solution until no enzyme can be detected in the washing solution. The activity of the washing solution was determined by adding ABTS into the specimen taken from the washing water, the absorbance of which at the wavelength of $420 \mathrm{~nm}$ after reaction for $5 \mathrm{~min}$ was recorded. If the absorbance value was less than 0.1 , it could be considered as no enzyme in the washing water.

\subsection{Structural Characterization}

The morphology of the electrospun PAN nanofibers before and after amidoxime modification as well as metal ion chelation was characterized by scanning electron microscope (SEM) (Quanta 200, Holland FEI Company, Eindhoven, The Netherlands. The samples were sputter coated with a thin layer of Au nanoparticles to reduce the charging effects.

Fourier Transform Infrared Spectroscopy (FTIR) (Nicolet Nexus, Thermo Electron Corporation, Waltham, MA, USA) was employed here to analyze the chemical structure of PAN and AOPAN nanofibrous membrane in the range of $4000-400 \mathrm{~cm}^{-1}$, using an Attenuated total reflectance (ATR) FTIR method. The spectra were recorded with 16 scans with a resolution of $4 \mathrm{~cm}^{-1}$.

Energy dispersive X-ray analysis (EDX) (Hitachi H-7500 transmission electron microscope, Tokyo, Japan) was used here to further confirm the existence of the metal ions chelated by the AOPAN nanofibrous membranes. Besides, the concentration of the metal ions was determined by atomic absorption spectroscopy (AAS) (AA-220, Varian, Palo Alto, CA, USA).

\subsection{Activity Assays of Free and Immobilized Laccase}

The immobilized enzyme activity was assayed at $30{ }^{\circ} \mathrm{C}$ using ABTS as the substrate. The detailed process was reported in our previous paper [23].

Kinetic tests were carried out at $30{ }^{\circ} \mathrm{C}$ in $100 \mathrm{mM}$ sodium acetate $(\mathrm{pH}=4.5)$ buffer using ABTS as the substrate, with the substrate concentration varied from 0.1 to $1 \mathrm{mM}$. The kinetic parameters of $K_{\mathrm{m}}$ and $V_{\max }$ were calculated according to the Lineweaver-Burk double reciprocal models [24].

To determine the optimum $\mathrm{pH}$, the immobilized enzymes were incubated in $100 \mathrm{mM}$ sodium acetate buffers with $\mathrm{pH}$ ranging from 2 to 7 at $4{ }^{\circ} \mathrm{C}$ for $2 \mathrm{~h}$ and then assayed for activity, while the optimum temperature was determined by the activities of the immobilized enzymes incubated in buffers ( $\mathrm{pH} 4.5$ ) for $5 \mathrm{~min}$ at specific temperatures varying from 30 to $65^{\circ} \mathrm{C}$ before adding ABTS.

The storage stability of the immobilized enzyme was determined by the activity retention ratio during storage at $4{ }^{\circ} \mathrm{C}$ in $100 \mathrm{mM}$ sodium acetate buffer solution ( $\left.\mathrm{pH} 4.5\right)$, at a regular intervals up to 20 days. Besides, the operational stability was studied by repeated usage for about 10 times, and the relative enzyme activity was recorded. The experiments were carried out at $30{ }^{\circ} \mathrm{C}, \mathrm{pH} 4.5$.

\section{Results and Discussion}

\subsection{Characterization of the Amidoximized PAN}

The SEM images of the PAN and AOPAN nanofibers are shown in Figure 2a,b, respectively. Compared with PAN nanofibers, the AOPAN nanofibers (51.7\% conversion) showed an almost 
similar morphology and no cracks or physical degradation was seen. However, the overall fibrous structure became more compact and the fibers were curved and entangled with each other, which could explain the reason why after amidoxime modification, the nanofibrous membrane became stiff and brittle. The FTIR spectra of PAN and AOPAN nanofibrous membranes are also presented in Figure 2c. Compared with the pristine PAN nanofibrous membrane, the FTIR spectrum of the AOPAN nanofibrous membrane showed some new peaks. The characteristic bands located at $3500-3100 \mathrm{~cm}^{-1}$, $1577 \mathrm{~cm}^{-1}, 1640 \mathrm{~cm}^{-1}, 1161 \mathrm{~cm}^{-1}$, and $987 \mathrm{~cm}^{-1}$ could be respectively attributed to the stretching vibration of $\mathrm{O}-\mathrm{H}, \mathrm{C}=\mathrm{N}, \mathrm{N}-\mathrm{H}, \mathrm{C}-\mathrm{N}$ and $\mathrm{N}-\mathrm{O}$, indicating the introduction of amidoxime group [21,25].

Figure 2. SEM Images of (a) pristine PAN; and (b) AOPAN nanofibrous membrane; and (c) FTIR spectra of PAN and AOPAN nanofibrous membrane.
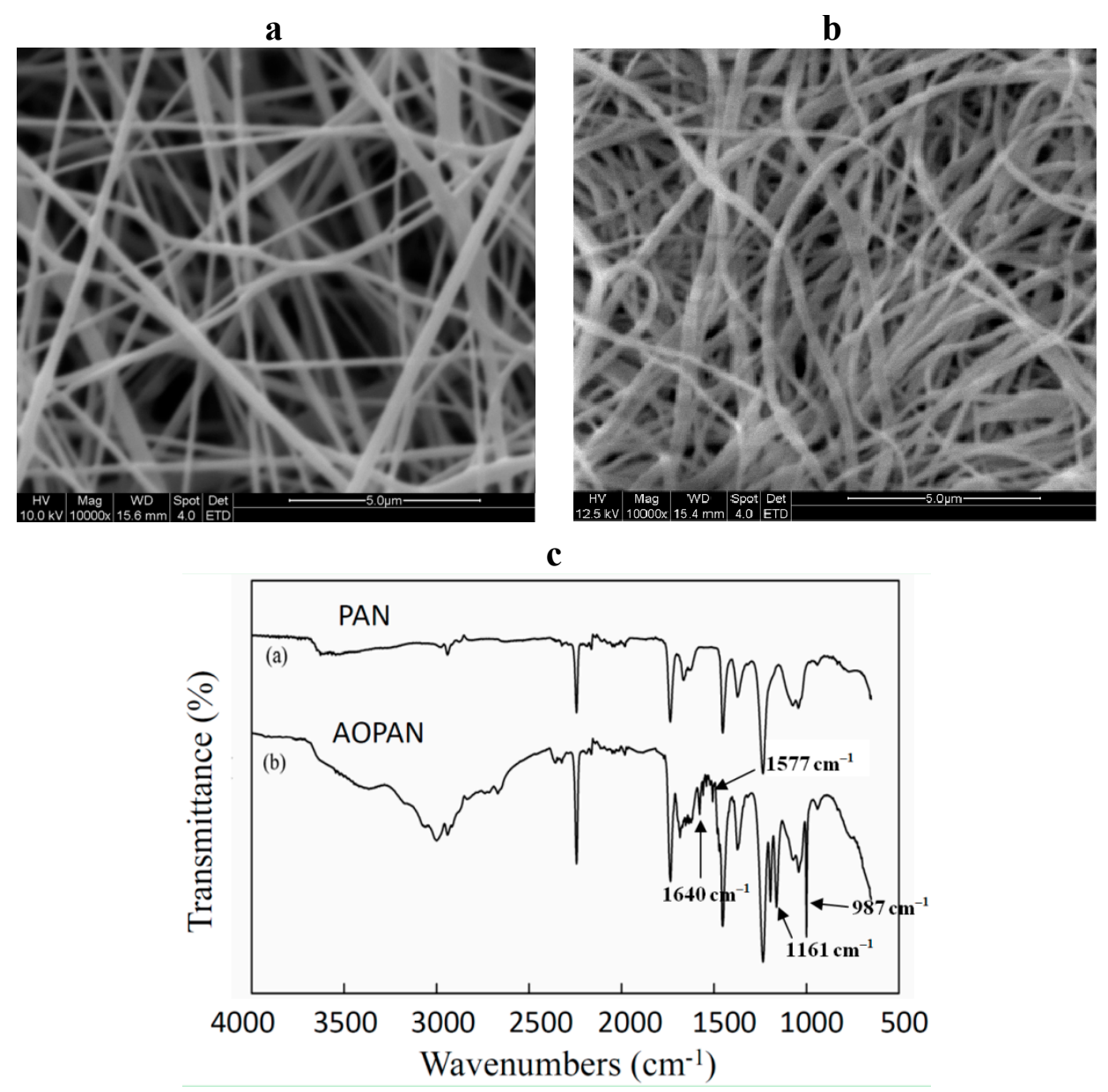

\subsection{Characterization of the Metal Ion Chelated PAN Nanofibrous Membranes}

The morphology and the respective elemental analysis of the metal ion chelated AOPAN nanofibrous membranes (33\% conversion) were recorded by SEM (Figure 3) and EDX (Figure 4). From the SEM images (Figure 3a-d), it can be observed that the metal ion chelated nanofibers showed a similar structure as that of the AOPAN. The fibers were distorted and entangled together, and no sign of physical cracks was seen. Besides, the results of the EDX (Figure 4a-e) confirmed the existence of the metal ions. 
Figure 3. SEM of metal ion chelated nanofibrous membranes (a) Fe(III)-AOPAN; (b) $\mathrm{Cu}(\mathrm{II})-\mathrm{AOPAN}$; (c) Ni(II)-AOPAN; and (d) Cd(II)-AOPAN.
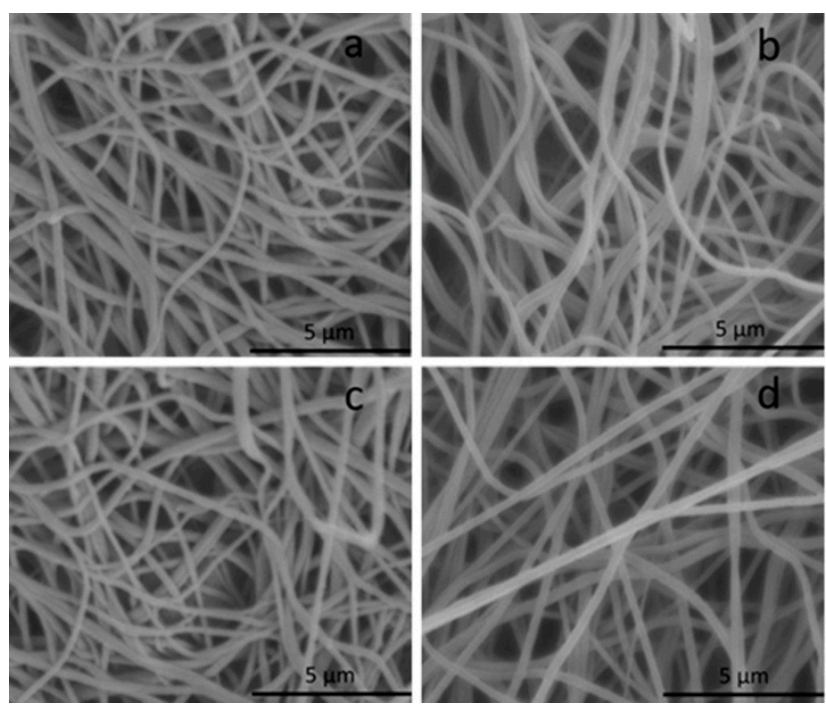

Figure 4. EDX of metal ion chelated nanofibrous membranes: (a) AOPAN; (b) Fe(III)-AOPAN; (c) Cu(II)-AOPAN; (d) Ni(II)-AOPAN; and (e) Cd(II)-AOPAN.

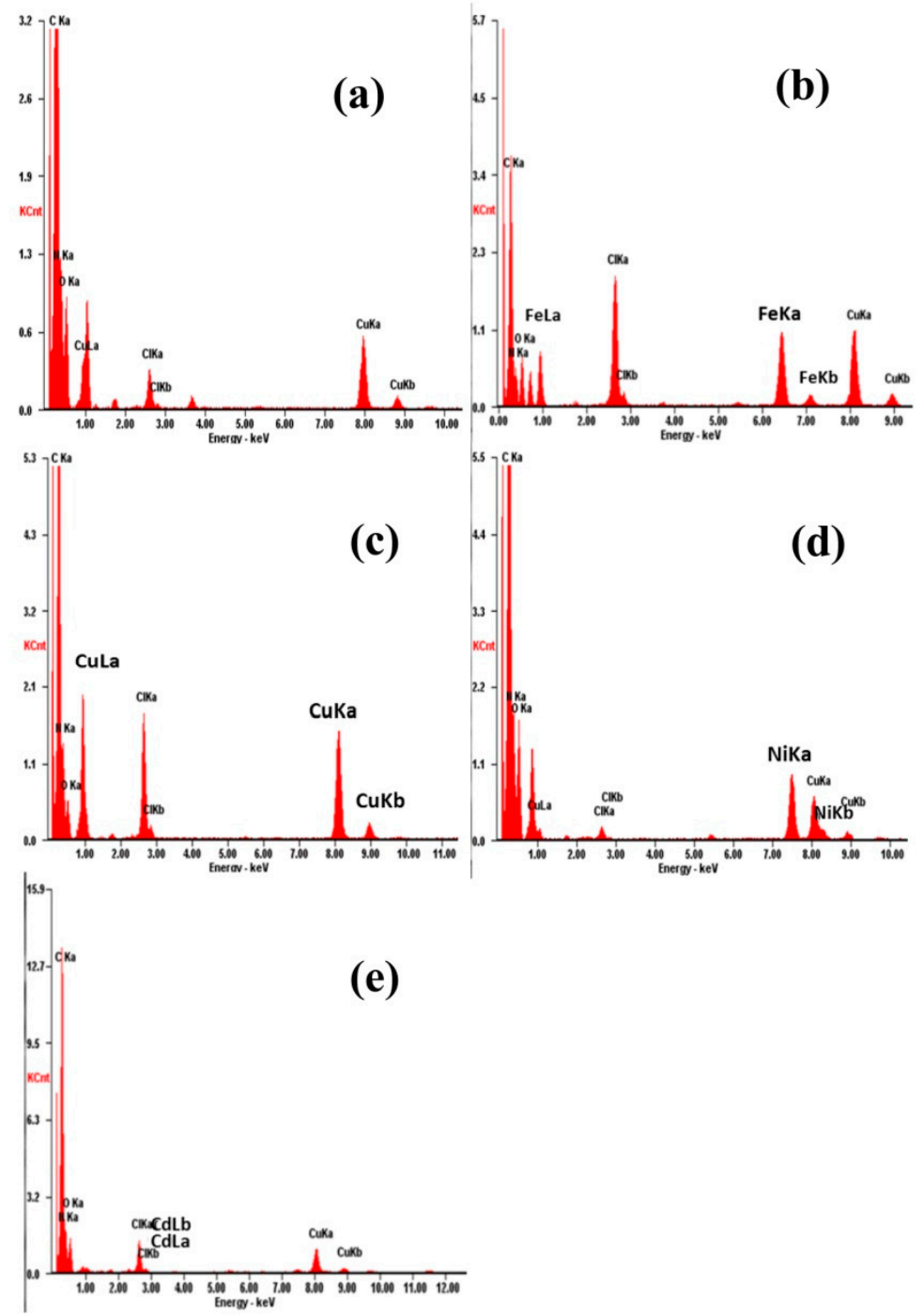




\subsection{The Coordination of Metal Ions and Their Properties in Enzyme Immobilization}

The amount of metal ions adsorbed onto AOPAN nanofibrous membranes ( $45 \%$ conversion) in three different concentrations $\left(100 \mathrm{mg} \cdot \mathrm{L}^{-1}, 500 \mathrm{mg} \cdot \mathrm{L}^{-1}, 1000 \mathrm{mg} \cdot \mathrm{L}^{-1}\right)$ were shown in Figure $5 \mathrm{a}$. It could be clearly seen that with the increase of metal ion concentration, the amount of the chelated metal ions by AOPAN nanofibrous membrane was also increased. Besides, the four metal ions at the same concentration showed different behavior in the chelation process. The adsorption capacity followed the order as $\mathrm{Fe}^{3+}>\mathrm{Cu}^{2+}>\mathrm{Ni}^{2+}>\mathrm{Cd}^{2+}$. The adsorption behavior versus time was also studied and the results were presented in Figure $5 \mathrm{~b}$. The AOPAN nanofibrous membrane with a conversion rate of 39\% was chosen for this experiment. During the first $6 \mathrm{~h}$, the adsorbed metal ions were sharply increased. After that, it achieved equilibrium value.

The amount of the adsorbed enzymes on four different metal ion chelated membranes was calculated by the method of Bradford [23], and the results were illustrated by Figure 5c. As can be seen, the Fe-AOPAN and $\mathrm{Cu}-\mathrm{AOPAN}$ adsorbed the most enzymes, Ni-AOPAN adsorbed relatively less enzymes, and the Cd-AOPAN showed the least, from which it could be inferred that the amount rather than the category of metal ion determined the final amount of adsorbed enzyme. After enzyme immobilization, the surface of the nanofibers are generally uniform while in some region small enzyme aggregates can be seen (Figure 5d).

Figure 5. (a) Coordination quantities of metal ions chelated by AOPAN nanofibrous membranes $\left(\mathrm{pH}=4\right.$, temperature at $30^{\circ} \mathrm{C}$, reaction time $\left.=72 \mathrm{~h}\right)$; (b) Relationship between reaction time and coordination quantities (the concentration of the solution was $500 \mathrm{mg} \cdot \mathrm{L}^{-1}, \mathrm{pH}=4$, temperature at $30^{\circ} \mathrm{C}$ ); (c) Amount of bound enzymes on different metal ion chelated AOPAN nanofibers; and (d) SEM of Fe-AOPAN nanofibrous membrane after enzyme immobilization.
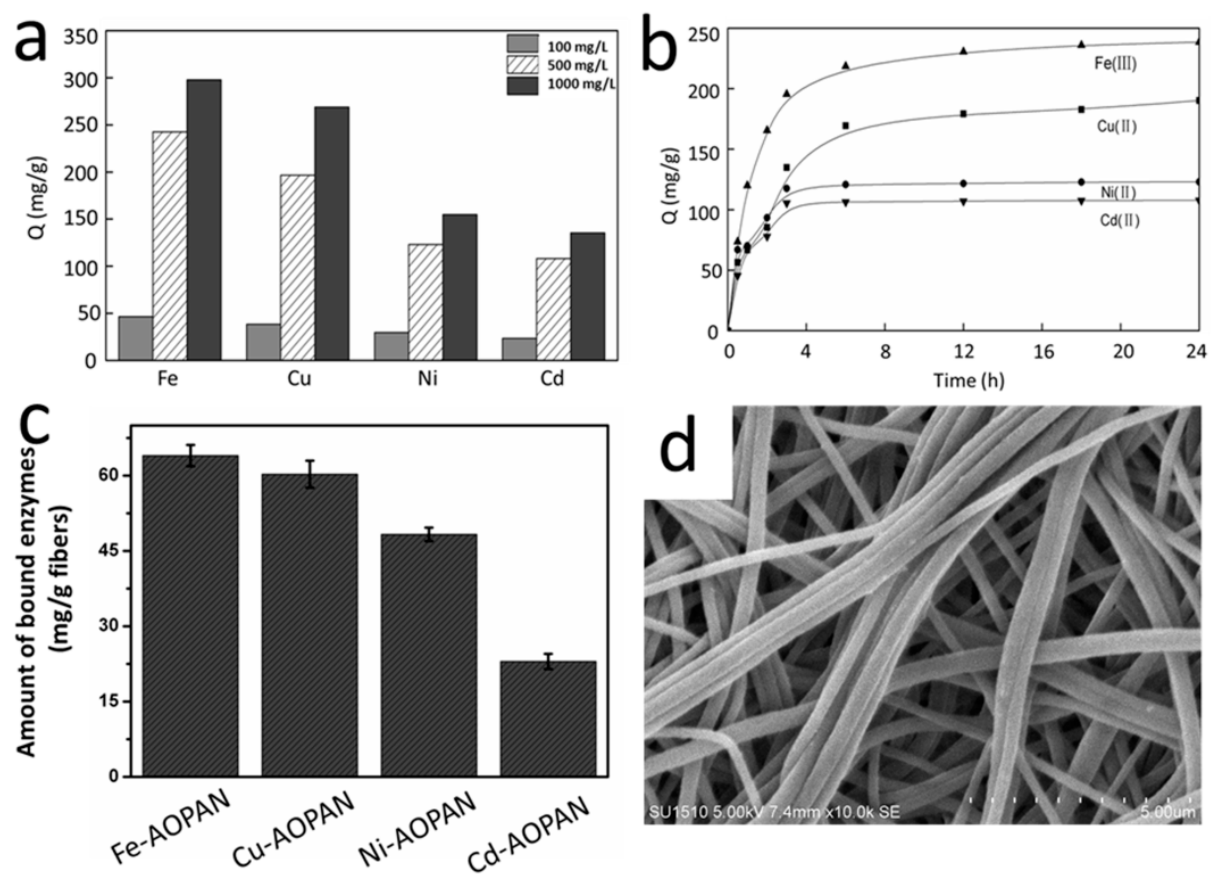


\subsection{Properties of the Immobilized Enzyme}

\subsubsection{Kinetic Properties}

The $K_{\mathrm{m}}$ values for free and immobilized laccase (Fe-AOPAN-Lac, Cu-AOPAN-Lac, Ni-AOPAN-Lac, Cd-AOPAN-Lac) were $0.114,2.713,0.84,1.53,1.21 \mathrm{mM} \cdot \mathrm{L}^{-1}$, respectively. After enzyme immobilization, the $K_{\mathrm{m}}$ values were generally increased; indicating a lower affinity for the substrate caused by diffusion limitations and decreased protein flexibility after immobilization [15].

\subsubsection{Optimum $\mathrm{pH}$}

Effect of $\mathrm{pH}$ on the activity of the free and immobilized laccase on AOPAN chelated with different metal ions $\left(\mathrm{Fe}^{3+}, \mathrm{Cu}^{2+}, \mathrm{Ni}^{2+}, \mathrm{Cd}^{2+}\right)$ was investigated at different $\mathrm{pH}$ values ranging from 2 to 7 (Figure 6a). Relative activity was defined as the percentage of the activity relative to the maximal activity which was set as $100 \%$. The maximal activity of the free and immobilized laccase was exhibited at $\mathrm{pH} 3.5$ and $\mathrm{pH} 4.0$, respectively. This peak-shift phenomenon can be explained by the electrostatic interaction influenced by the carrier microenvironment [26]. Similar behavior was also observed in other studies [26,27]. As seen in Figure 5a, the immobilized laccase generally showed a broader $\mathrm{pH}$-activity profile than that of the free laccase, indicating that the immobilization methods preserved the enzyme activity in a wider $\mathrm{pH}$ range [28]. Among the four immobilized laccase, the Fe-AOPAN-Lac showed the best resistance to $\mathrm{pH}$ changes, while the Cd-AOPAN-Lac showed the least. Besides, the activity retention during $\mathrm{pH}$ changes of $\mathrm{Cu}-\mathrm{AOPAN}-\mathrm{Lac}$ and Ni-AOPAN-Lac was relatively lower as compared to that of Fe-AOPAN-Lac, following the same trend.

\subsubsection{Optimum Temperature}

The influence of temperature on the activity of the free and immobilized laccase is shown in Figure 6b. The immobilized enzymes were incubated in buffers $(\mathrm{pH} 4.5)$ for $5 \mathrm{~min}$ at different temperatures varying from 30 to $65{ }^{\circ} \mathrm{C}$ before adding ABTS. It could be observed that activities of both free and immobilized laccase were strongly dependent on temperature, and the maximal activity was exhibited at $50{ }^{\circ} \mathrm{C}$. Compared with free laccase, the immobilized enzyme showed a broader temperature profile. The improvement in resistance against temperature was probably due to a reduction in molecular mobility and conformational changes by coordination into the metal chelated support. The immobilized enzymes generally showed a similar profile trend of temperature stability in the range of $30-65{ }^{\circ} \mathrm{C}$. Among all the immobilized enzymes, the Fe-AOPAN-Lac showed the best temperature stability over a broad range, Cd-AOPAN-Lac had a very close trend to the free enzyme, while $\mathrm{Cu}-\mathrm{AOPAN}-\mathrm{Lac}$ and Ni-AOPAN-Lac showed relatively better temperature stability than that of free laccase with a quite similar trend.

\subsubsection{Storage Stability}

The storage stability of the immobilized enzymes was also studied and the results are presented in Figure 6c. The immobilized enzymes showed better storage stability than that of the free enzyme. The laccase immobilized on Fe-AOPAN, Cu-AOPAN and Ni-AOPAN composite nanofibers showed 
relatively higher storage stability than that of Cd-AOPAN. After being stored for 20 days, the $\mathrm{Cu}-\mathrm{AOPAN}-\mathrm{Lac}$ retained more than $65 \%$ of its initial activity, which was higher than the results we previously reported [19].

\subsubsection{Operational Stability}

The operational stability of the immobilized laccase is presented in Figure 6d. Decrease in the enzyme activity upon repeated usage was expected due to the fact that enzymes may denature or desorbed during repeated usage. After 10 repeated usage, the activity retention ratio of Fe-AOPAN-Lac, $\mathrm{Cu}-\mathrm{AOPAN}-\mathrm{Lac}, \mathrm{Ni}-\mathrm{AOPAN}-\mathrm{Lac}, \mathrm{Cd}-\mathrm{AOPAN}-\mathrm{Lac}$ were $41.25 \%, 49.17 \%, 26.40 \%, 0.23 \%$, respectively. Among the four immobilized enzymes, Fe-AOPAN-Lac and Cu-AOPAN-Lac well retained their activity during repeated usage, showing their potential value in future application. However, Cd-AOPAN-Lac had lost all the activity since the 6th operation process.

Figure 6. The properties of both free and immobilized enzymes: (a) optimum $\mathrm{pH}$; (b) optimum temperature; (c) storage stability; and (d) operational stability.
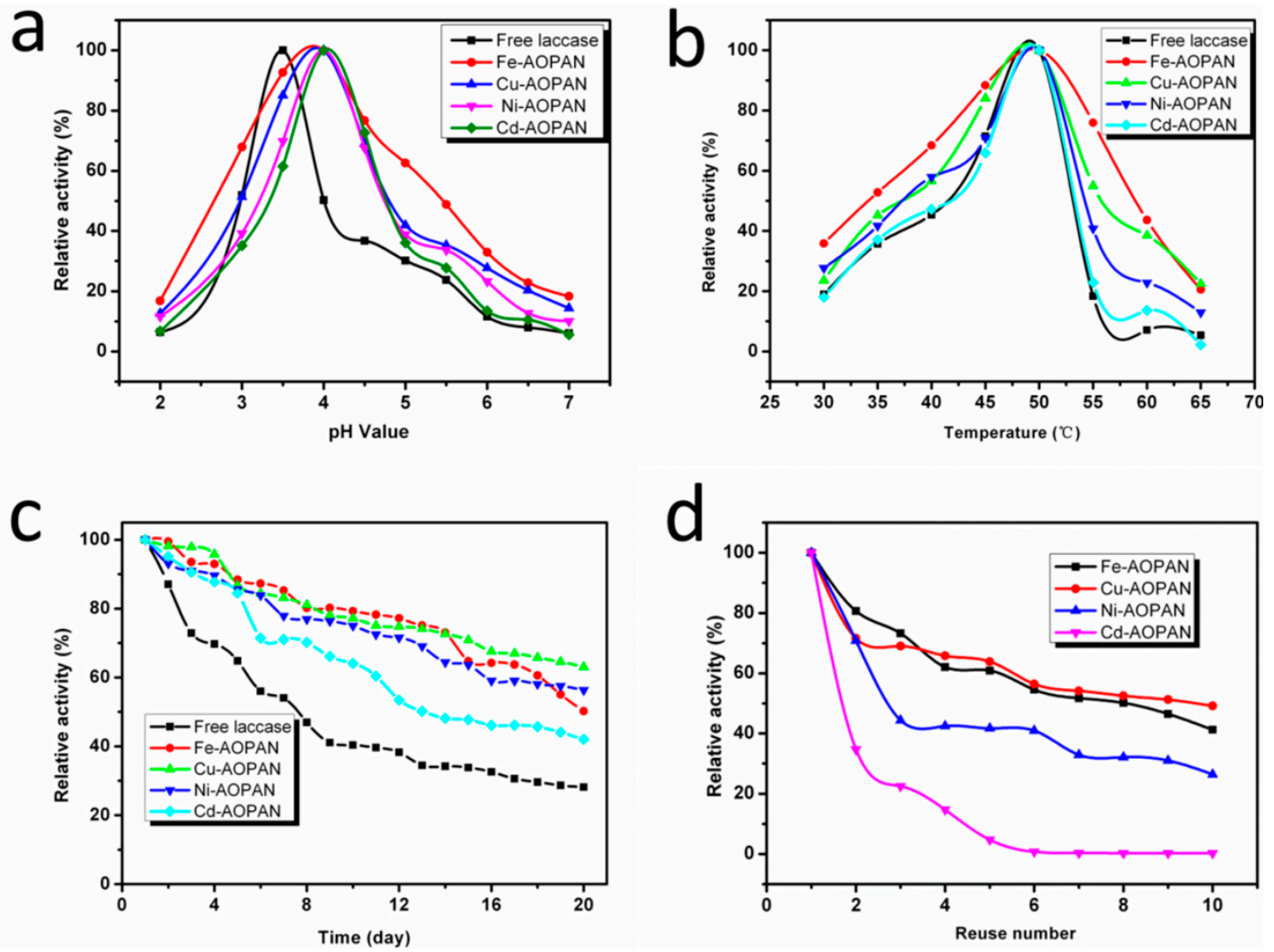

Those results of the immobilized enzyme stability presented hereinbefore can be interpreted in terms of the size of the metal ions and electric density which could further determine the coordination capability between the chelate fiber ligand and the metal ions. According to Lewis theory [29] and Pearson rules [30], metal ions, which have small size, high positive electric, low polarization ability, and the property of being difficult to be deformed, are called hard acid. Hard acid such as $\mathrm{Fe}^{3+}$ easily accept the electron pair provided by the ligand. In contrast, those metal ions with large size, low positive electric, high polarization ability are called soft acid, which cannot easily accept the 
electric pair from ligand. For example, $\mathrm{Cd}^{2+}$ is a kind of soft acid. Besides, the properties of some other metal ions fall in between of hard acid and soft acid, such as $\mathrm{Cu}^{2+}$ and $\mathrm{Ni}^{2+}$. The amino group existed in both AOPAN and enzyme is a kind of hard alkali, which has strong electronegativity, and the polarization capability of the electron pair provider is low. According to Pearson, hard acid prefers to combine with hard alkali, while soft alkali tends to react with soft alkali. In addition, the coordination compound formed between hard acid and hard alkali, soft acid and soft alkali are relatively stable, so the coordination between the AOPAN and $\mathrm{Fe}^{3+}$, enzyme and $\mathrm{Fe}^{3+}$ is relatively more stable than that of AOPAN and $\mathrm{Cd}^{2+}$, enzyme and $\mathrm{Cd}^{2+}$. Same explanation applies to that of $\mathrm{Cu}^{2+}$ and $\mathrm{Ni}^{2+}$. Therefore, the general enzyme stability immobilized onto different supports follows the order as Fe-AOPAN-Lac $>$ Cu-AOPAN-Lac $>$ Ni-AOPAN-Lac $>$ Cd-AOPAN-Lac.

\subsection{Enzyme Immobilization on the AOPAN Chelated with Four Metal Ions}

The metal ion chelated AOPAN nanofibrous membranes used as enzyme carrier can improve the properties of the immobilized enzyme to different extent. Therefore, in this work, we further explored the properties of the immobilized enzyme on the AOPAN nanofibrous membrane chelated with the four metal ions mentioned above.

\subsubsection{Coordination with Mixed Metal Ions by AOPAN Nanofibers}

Table 1 showed the results of the concentration of the metal ions before and after coordination process in a mixed solution with four metal ions. In a mixed solution, the $\mathrm{Fe}^{3+}$ and $\mathrm{Cu}^{2+}$ still showed better coordination properties than $\mathrm{Ni}^{2+}$ and $\mathrm{Cd}^{2+}$, which was in correspondence with the results of the individual metal ions adsorption.

Table 1. Coordination characteristics of chelating nanofibers with mixed metal ions.

\begin{tabular}{ccc}
\hline Metal Ions & $\begin{array}{c}\text { Before Coordination } \\
\text { Reaction }\left(\mathbf{m g} \cdot \mathbf{L}^{-\mathbf{1}}\right)\end{array}$ & $\begin{array}{c}\text { After Coordination } \\
\text { Reaction }\left(\mathbf{m g} \cdot \mathbf{L}^{-\mathbf{1}}\right)\end{array}$ \\
\hline $\mathrm{Fe}^{3+}$ & 2.640 & 0.920 \\
$\mathrm{Cu}^{2+}$ & 2.899 & 0.613 \\
$\mathrm{Ni}^{2+}$ & 7.290 & 7.080 \\
$\mathrm{Cd}^{2+}$ & 5.560 & 5.360 \\
\hline
\end{tabular}

3.5.2. Properties of the Immobilized Enzyme on the Mixed Metal Ion Chelated AOPAN Nanofibrous Membrane

The properties of the immobilized enzymes on mixed metal ion chelated AOPAN nanofibrous membrane were studied and presented in Figure 7. The optimum $\mathrm{pH}$ and temperature of the immobilized enzyme were at 4.0 and $50{ }^{\circ} \mathrm{C}$ (Figure 7a,b), respectively, which was in consistent with that of the immobilized enzymes on individual metal ion chelated membranes. Moreover, the resistance to $\mathrm{pH}$ and temperature changes was generally increased. Besides, the storage stability and the reusability (Figure 7c,d) were similar to that of the Fe-AOPAN-Lac. 
Figure 7. The properties of the immobilized enzyme on mixed metal ion chelated AOPAN nanofibrous membrane: (a) optimum pH; (b) optimum temperature; (c) storage stability; and (d) operational stability.
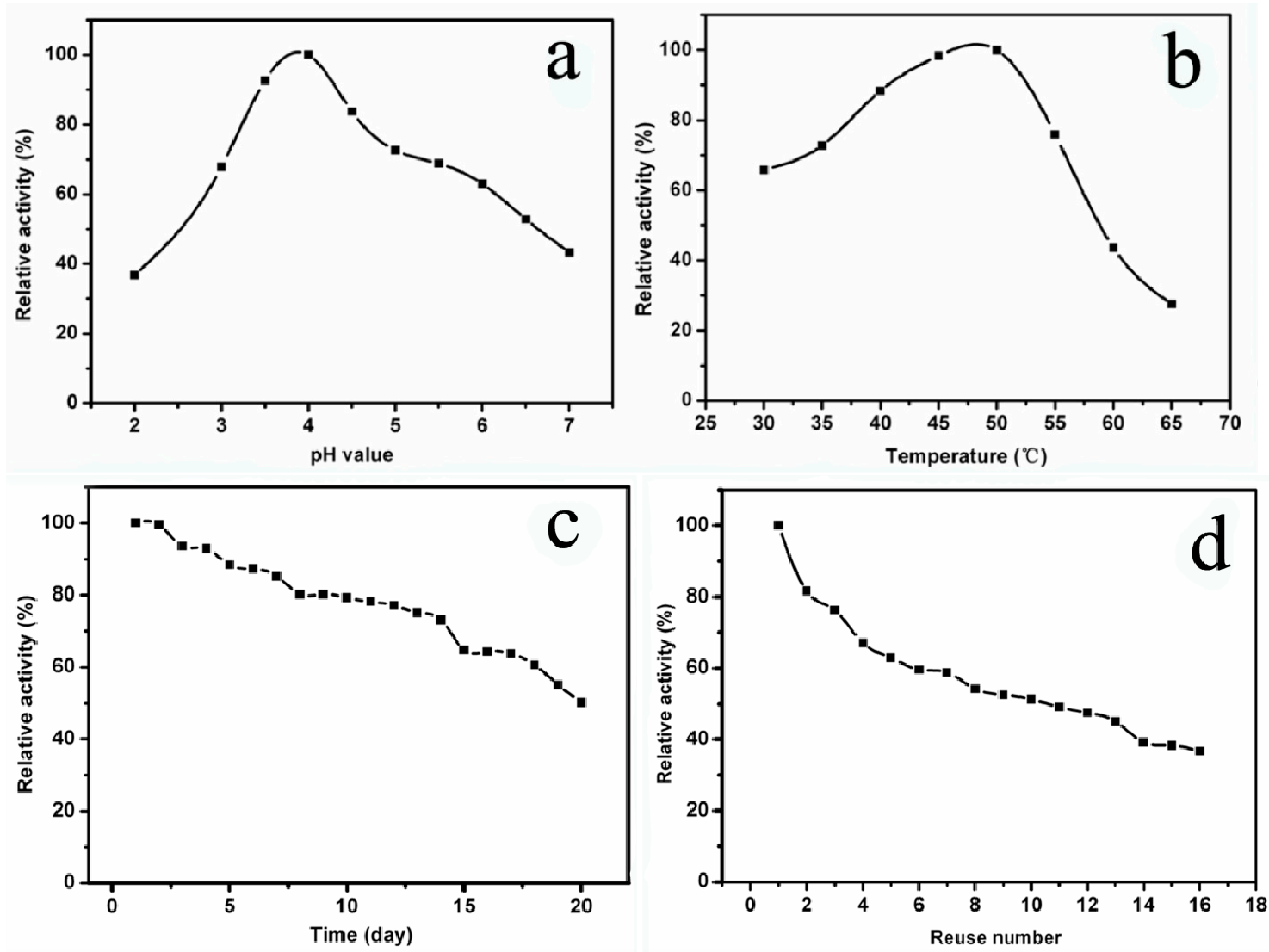

\section{Conclusions}

AOPAN nanofibrous membranes chelated with different metal ions including $\mathrm{Fe}^{3+}, \mathrm{Cu}^{2+}, \mathrm{Ni}^{2+}, \mathrm{Cd}^{2+}$ as well as the combination of these four metal ions were successfully prepared and used as the carrier for laccase. The immobilization process enhanced the enzyme stability against $\mathrm{pH}$ and temperature changes as well as the storage stability. As for the reusability, the Fe-AOPAN-Lac and Cu-AOPAN-Lac as well as the mixed metal ion-AOPAN-Lac showed ideal results. In conclusion, all of the four metal ions contributed to improving the stability of the immobilized enzyme, and the properties of the immobilized enzymes were more dependent on the quantity of the chelated metal ions than on the metal ion itself. Therefore AOPAN nanofibrous membranes chelated with various metal ions can be an ideal support for enzyme immobilization.

\section{Acknowledgments}

This work was financially supported by the National High-tech R\&D Program of China (No.2012AA030313), Changjiang Scholars and Innovative Research Team in University (No.IRT1135), National Natural Science Foundation of China (No.51006046 and No.51163014) and the Priority Academic Program Development of Jiangsu Higher Education Institutions. 


\section{Author Contributions}

All listed authors contributed to this work. Qingqing Wang was responsible for the preparation of the membrane, the enzyme immobilization, analyzing the data as well as writing this manuscript; Jing Cui, Jinning Zhang, Guohui Li did the optimum pH, temperature, storage stability and operational stability. Qufu Wei and Fenglin Huang designed this work and obtained financial support.

\section{Conflicts of Interest}

The authors declare no conflict of interest.

\section{References}

1. Galhaup, C.; Goller, S.; Peterbauer, C.K.; Strauss, J.; Haltrich, D. Characterization of the major laccase isoenzyme from trametes pubescens and regulation of its synthesis by metal ions. Microbiology 2002, 148, 2159-2169.

2. Madhavi, V.; Lele, S.S. Laccase: Properties and applications. Bioresources 2009, 4, 1694-1717.

3. Flory, A.R.; Requesens, D.V.; Devaiah, S.P.; Teoh, K.T.; Mansfield, S.D.; Hood, E.E. Development of a green binder system for paper products. BMC Biotechnol. 2013, 13, doi:10.1186/1472-6750-13-28.

4. Fackler, K.; Kuncinger, T.; Ters, T.; Srebotnik, E. Laccase-catalyzed functionalization with 4-hydroxy-3-methoxybenzylurea significantly improves internal bond of particle boards. Holzforschung 2008, 62, 223-229.

5. Ashrafi, S.D.; Rezaei, S.; Forootanfar, H.; Mahvi, A.H.; Faramarzi, M.A. The enzymatic decolorization and detoxification of synthetic dyes by the laccase from a soil-isolated ascomycete, paraconiothyrium variabile. Int. Biodeterior. Biodegrad. 2013, 85, 173-181.

6. Zhang, Y.; Zeng, Z.T.; Zeng, G.M.; Liu, X.M.; Liu, Z.F.; Chen, M.; Liu, L.F.; Li, J.B.; Xie, G.X. Effect of triton $\mathrm{X}-100$ on the removal of aqueous phenol by laccase analyzed with a combined approach of experiments and molecular docking. Colloid Surf. B 2012, 97, 7-12.

7. Dhillon, G.S.; Kaur, S.; Brar, S.K.; Verma, M. Flocculation and haze removal from crude beer using in-house produced laccase from trametes versicolor cultured on brewer's spent grain. J. Agric. Food Chem. 2012, 60, 7895-7904.

8. Basto, C.; Tzanov, T.; Cavaco-Paulo, A. Combined ultrasound-laccase assisted bleaching of cotton. Ultrason. Sonochem. 2007, 14, 350-354.

9. Fernandez-Fernandez, M.; Sanroman, M.A.; Moldes, D. Recent developments and applications of immobilized laccase. Biotechnol. Adv. 2013, 31, 1808-1825.

10. Qiu, H.J.; Xu, C.X.; Huang, X.R.; Ding, Y.; Qu, Y.B.; Gao, P.J. Immobilization of laccase on nanoporous gold: Comparative studies on the immobilization strategies and the particle size effects. J. Phys. Chem. C 2009, 113, 2521-2525.

11. Feng, Q.A.; Xia, X.; Wei, A.F.; Wang, X.Q.; Wei, Q.F.; Huo, D.Y.; Wei, A.J. Preparation of $\mathrm{Cu}(\mathrm{II})$-chelated poly(vinyl alcohol) nanofibrous membranes for catalase immobilization. J. Appl. Polym. Sci. 2011, 120, 3291-3296. 
12. Bayramoglu, G.; Yilmaz, M.; Arica, M.Y. Reversible immobilization of laccase to poly(4-vinylpyridine) grafted and $\mathrm{Cu}(\mathrm{II})$ chelated magnetic beads: Biodegradation of reactive dyes. Bioresour. Technol. 2010, 101, 6615-6621.

13. Mazur, M.; Krysinski, P.; Michota-Kaminska, A.; Bukowska, J.; Rogalski, J.; Blanchard, G.J. Immobilization of laccase on gold, silver and indium tin oxide by zirconium-phosphonatecarboxylate (ZPC) coordination chemistry. Bioelectrochemistry 2007, 71, 15-22.

14. Teerapatsakul, C.; Bucke, C.; Parra, R.; Keshavarz, T.; Chitradon, L. Dye decolorisation by laccase entrapped in copper alginate. World J. Microbiol. Biotechnol. 2008, 24, 1367-1374.

15. Lu, L.; Zhao, M.; Wang, Y. Immobilization of laccase by alginate-chitosan microcapsules and its use in dye decolorization. World J. Microbiol. Biotechnol. 2007, 23, 159-166.

16. Wang, Z.G.; Wan, L.S.; Liu, Z.M.; Huang, X.J.; Xu, Z.K. Enzyme immobilization on electrospun polymer nanofibers: An overview. J. Mol. Catal. B Enzym. 2009, 56, 189-195.

17. Xu, R.; Chi, C.L.; Li, F.T.; Zhang, B.R. Laccase-polyacrylonitrile nanofibrous membrane: Highly immobilized, stable, reusable, and efficacious for 2,4,6-trichlorophenol removal. ACS Appl. Mater. Int. 2013, 5, 12554-12560.

18. Saeed, K.; Haider, S.; Oh, T.J.; Park, S.Y. Preparation of amidoxime-modified polyacrylonitrile (pan-oxime) nanofibers and their applications to metal ions adsorption. J. Membr. Sci. 2008, 322, 400-405.

19. Feng, Q.; Wang, Q.Q.; Tang, B.; Wei, A.F.; Wang, X.Q.; Wei, Q.F.; Huang, F.L.; Cai, Y.B.; Hou, D.Y.; Bi, S.M. Immobilization of catalases on amidoxime polyacrylonitrile nanofibrous membranes. Polym. Int. 2013, 62, 251-256.

20. Ding, Z.Y.; Peng, L.; Chen, Y.Z.; Zhang, L.; Gu, Z.H.; Shi, G.Y.; Zhang, K.C. Production and characterization of thermostable laccase from the mushroom, ganoderma lucidum, using submerged fermentation. Afr. J. Microbiol. Res. 2012, 6, 1147-1157.

21. Huang, F.L.; Xu, Y.F.; Liao, S.Q.; Yang, D.W.; Hsieh, Y.L.; Wei, Q.F. Preparation of amidoxime polyacrylonitrile chelating nanofibers and their application for adsorption of metal ions. Materials 2013, 6, 969-980.

22. Zhang, P.; Wang, Q.Q.; Zhang, J.N.; Li, G.H.; Wei, Q.F. Preparation of amidoxime-modified polyacrylonitrile nanofibers immobilized with laccase for dye degradation. Fiber. Polym. 2014, $15,30-34$.

23. Wang, Q.Q.; Peng, L.; Du, Y.Z.; Xu, J.; Cai, Y.B.; Feng, Q.; Huang, F.L.; Wei, Q.F. Fabrication of hydrophilic nanoporous PMMA/o-MMT composite microfibrous membrane and its use in enzyme immobilization. J. Porous Mater. 2013, 20, 457-464.

24. Wang, Q.Q.; Peng, L.; Li, G.H.; Zhang, P.; Li, D.W.; Huang, F.L.; Wei, Q.F. Activity of laccase immobilized on $\mathrm{TiO}_{2}$-montmorillonite complexes. Int. J. Mol. Sci. 2013, 14, 12520-12532.

25. Bilba, N.; Bilba, D.; Moroi, G. Synthesis of a polyacrylamidoxime chelating fiber and its efficiency in the retention of palladium ions. J. Appl. Polym. Sci. 2004, 92, 3730-3735.

26. Arica, M.Y. Immobilization of polyphenol oxidase on carboxymethylcellulose hydrogel beads: Preparation and characterization. Polym. Int. 2000, 49, 775-781.

27. Liu, Y.Y.; Zeng, Z.T.; Zeng, G.M.; Tang, L.; Pang, Y.; Li, Z.; Liu, C.; Lei, X.X.; Wu, M.S.; Ren, P.Y.; et al. Immobilization of laccase on magnetic bimodal mesoporous carbon and the application in the removal of phenolic compounds. Bioresour. Technol. 2012, 115, 21-26. 
28. Bayramoglu, G.; Yilmaz, M.; Senel, A.U.; Arica, M.Y. Preparation of nanofibrous polymer grafted magnetic poly(GMA-MMA)-g-MAA beads for immobilization of trypsin via adsorption. Biochem. Eng. J. 2008, 40, 262-274.

29. Zhang, L.H.; Zhang, X.S.; Li, P.P.; Zhang, W.Q. Effective $\mathrm{Cd}^{2+}$ chelating fiber based on polyacrylonitrile. React. Funct. Polym. 2009, 69, 48-54.

30. Horzum, N.; Boyaci, E.; Eroglu, A.E.; Shahwan, T.; Demir, M.M. Sorption efficiency of chitosan nanofibers toward metal ions at low concentrations. Biomacromolecules 2010, 11, 3301-3308.

(C) 2014 by the authors; licensee MDPI, Basel, Switzerland. This article is an open access article distributed under the terms and conditions of the Creative Commons Attribution license (http://creativecommons.org/licenses/by/3.0/). 